Check for updates

Cite this: RSC Adv., 2017, 7, 23709

\title{
Novel $\left[\mathrm{NF}_{2} \mathrm{O}\right]^{+}$and $\left[\mathrm{N}_{3} \mathrm{NFO}\right]^{+}$-based energetic oxidizers for solid propellants with super high specific impulse
}

\begin{abstract}
Yi Yu, (D) a Jifeng Chen, ${ }^{a}$ Rubo Zhang, ${ }^{b}$ Yuchuan Li ${ }^{\star a}$ and Siping Pang ${ }^{\star a}$
Novel $\left[\mathrm{NF}_{2} \mathrm{O}\right]^{+}$and $\left[\mathrm{N}_{3} \mathrm{NFO}\right]^{+}$-based energetic oxidizers were designed, and their structures, thermal stabilities, and energetic properties were investigated via density functional theory (DFT). The analysis of the bond dissociation energies (from 93.4 to $120.8 \mathrm{kcal} \mathrm{mol}^{-1}$ ) for the screened salts suggests that they possess better thermal stabilities than the reported $\left[\mathrm{NF}_{2} \mathrm{O}\right]^{+} \mathrm{SbF}_{6}{ }^{-}\left(89.8 \mathrm{kcal} \mathrm{mol}^{-1}\right)$, and compound 5 was the most stable energetic salt. All the screened salts possess a positive oxygen balance ranging from $13 \%$ to $50 \%$. Due to a positive oxygen balance, the specific impulses of the compounds 5, 11-14 (>300 s) were superior to those of ammonium perchlorate (AP) and ammonium dinitramide (ADN) when the optimized ratio of oxidizer/aluminium/PBAN (\%) was $76: 10: 14$. Considering their thermal stability and chemical reactivity, compounds 5 and 11 with super high specific impulses can be regarded as excellent candidates for novel potential solid propellants.
\end{abstract}

Received 21st March 2017

Accepted 13th April 2017

DOI: $10.1039 / \mathrm{c} 7 \mathrm{ra03304d}$

rsc.li/rsc-advances

1969 that it exists in an ionic form in its Lewis acid adducts. ${ }^{17}$ In

\section{Introduction}

Energetic oxidizers, such as ammonium perchlorate (AP) and ammonium dinitramide ( $\mathrm{ADN}$ ), are compounds that release excess of oxygen, which react with fuels and produce large amounts of hot gases for propulsion. ${ }^{1,2}$ With high densities and heats of formation, high specific impulse, and high thermal stabilities, energetic salts have been a research hotspot of explosive compounds, which are useful as propellants, explosives, and pyrotechnics. ${ }^{3-7}$ As two parts of energetic salts, the cations and anions take the role of fuels and oxidizers, respectively. The introduction of non-oxygen containing cations into the energetic salts will decrease the oxygen balance of the salts, restricting the promotion of the energetic performance of the energetic salts; thus, it is often sufficient to oxidize the carbon content only to $\mathrm{CO}$ and not to $\mathrm{CO}_{2}$ to achieve near maximum performance. $^{8}$ However, oxygen-containing cations remain elusive because once nitrated or oxidized, the ability of neutral Lewis bases to form cationic species is greatly reduced.,.$^{9,10}$ Therefore, novel oxidizers with oxygen-containing cations will be helpful to improve the oxygen balance and energetic performance of the energetic salts; for example, $\left[\mathrm{NF}_{2} \mathrm{O}\right]^{+}$and $\left[\mathrm{N}_{3} \mathrm{NFO}\right]^{+}$, which have been reported decades ago, but the research on these cations moved slowly due to their strong oxidizability and reactivity. ${ }^{11,12}$

The study history of $\left[\mathrm{NF}_{2} \mathrm{O}\right]^{+}$originated from the chemistry of trifluoramine oxide $\left(\mathrm{NF}_{3} \mathrm{O}\right)$ in the $1960 \mathrm{~s},{ }^{13-16}$ and it was found in

${ }^{a}$ School of Materials Science \& Engineering, Beijing Institute of Technology, Beijing 100081, PR China.E-mail: liyuchuan@bit.edu.cn; pangsp@bit.edu.cn

${ }^{b}$ School of Chemistry, Beijing Institute of Technology, Beijing 100081, PR China 1999, $\left[\mathrm{NF}_{2} \mathrm{O}\right]^{+}$was used as an intermediate to synthesize the amazing $\mathrm{N}_{5}{ }^{+}$cation. ${ }^{18}$ To date, only several $\left[\mathrm{NF}_{2} \mathrm{O}\right]^{+}$-based salts with paired anions such as $\mathrm{SbF}_{6}{ }^{-}, \mathrm{Sb}_{2} \mathrm{~F}_{11}{ }^{-}, \mathrm{AsF}_{6}{ }^{-}, \mathrm{BF}_{4}{ }^{-}$, and $\mathrm{B}_{2} \mathrm{~F}_{7}{ }^{-}$have been synthesized, among which $\left[\mathrm{NF}_{2} \mathrm{O}\right]^{+} \mathrm{SbF}_{6}{ }^{-}$was the most stable salt. ${ }^{19}$ As another fluoride oxide cation, $\left[\mathrm{N}_{3} \mathrm{NFO}\right]^{+}$was reported in the form of $\left[\mathrm{N}_{3} \mathrm{NFO}\right]^{+} \mathrm{SbF}_{6}{ }^{-}$in $2007,{ }^{20}$ which exists in the form of two different configurations: trans$\left[\mathrm{N}_{3} \mathrm{NFO}\right]^{+}$and cis- $\left[\mathrm{N}_{3} \mathrm{NFO}\right]^{+}$. Since then, no novel $\left[\mathrm{N}_{3} \mathrm{NFO}\right]^{+}-$ based salts have been experimentally or theoretically reported. These two cations compose of nitrogen, oxygen, and fluorine in their structures. On the one hand, contrary to the commonly used fuel cations, oxygen in their composition will help to improve the oxygen balance. On the other hand, fluorine can also act as a strong oxidizer to further improve the oxygen balance of the energetic salts. Moreover, hydrogen is not present in the cations, which helps to improve the entire density of the energetic salts. These characteristics make them excellent candidates as strong energetic oxidizers to be used as potential propellants when combined with appropriate anions. Fig. 1 demonstrates the superior specific impulse performance of oxygen-rich $\left[\mathrm{NF}_{2} \mathrm{O}\right]^{+}$and $\left[\mathrm{N}_{3} \mathrm{NFO}\right]^{+}$-based oxidizers in contrast to that of traditional fuel cation-based oxidizers, based on theoretical calculations.

Our previous study indicated that the combination of $\mathrm{AlF}_{4}{ }^{-}$ with a strong oxidizing $\mathrm{N}_{5}{ }^{+}$cation may stabilize the salt, ${ }^{21}$ which prompted us to pair $\mathrm{AlF}_{4}{ }^{-}$with the two cations to evaluate their stabilities. Additionally, the possibility of synthesizing novel $\left[\mathrm{NF}_{2} \mathrm{O}\right]^{+}$and $\left[\mathrm{N}_{3} \mathrm{NFO}\right]^{+}$salts with good stability lead us to carry out further investigations. To evaluate the role of the central atom in $\mathrm{SbF}_{6}{ }^{-}$for the stability of $\left[\mathrm{NF}_{2} \mathrm{O}\right]^{+}\left[\mathrm{SbF}_{6}\right]^{-}$, the $\mathrm{Sb}$ atom 


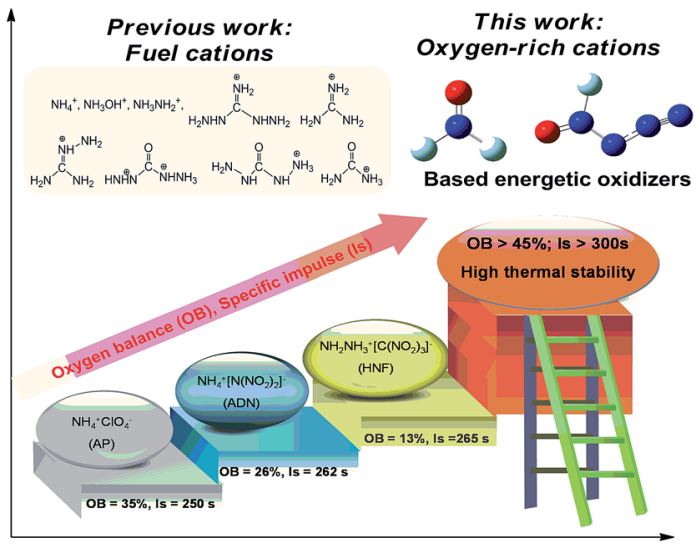

Fig. 1 The superior performance of oxygen-rich $\left[\mathrm{NF}_{2} \mathrm{O}\right]^{+}$and $\left[\mathrm{N}_{3} \mathrm{NFO}\right]^{+}$-based oxidizers in contrast to that of traditional fuel cationbased oxidizers.

was substituted by $\mathrm{Al}$ to estimate its stability. Herein, a series of novel $\left[\mathrm{NF}_{2} \mathrm{O}\right]^{+}$and $\left[\mathrm{N}_{3} \mathrm{NFO}\right]^{+}$salts with paired anions $\left(\mathrm{ClO}_{4}{ }^{-}\right.$, $\mathrm{NO}_{3}{ }^{-}, \mathrm{N}\left(\mathrm{NO}_{2}\right)_{2}{ }^{-}, \mathrm{SO}_{3} \mathrm{CF}_{3}{ }^{-}, \mathrm{SO}_{3} \mathrm{NF}_{2}{ }^{-}, \mathrm{AlF}_{4}{ }^{-}$, and $\mathrm{AlF}_{6}{ }^{-}$) were designed to study their structures, stabilities, and energetic performances. Via employing density functional theory, we screened out compounds with good stability and energetic performance, expanding the novel application of these cations.

\section{Computational details}

All the calculations were performed using the Gaussian 09 package. Geometry optimizations of the starting structures were carried out at the M06-2X level with the 6-311+G(d) basis set for the $\mathrm{C}, \mathrm{N}, \mathrm{F}, \mathrm{O}, \mathrm{Cl}, \mathrm{S}$, and $\mathrm{Al}$ atoms, and SDD for other heavy metal atoms. ${ }^{22}$ Note that the M06-2X functional is very suitable to multi-nitrogen or pure nitrogen molecules according to previous studies. ${ }^{23}$ Each optimized structure was confirmed as a local energy minima on the potential-energy surface without imaginary frequencies.

Based on the Born-Haber energy cycle, as shown in Scheme 1 , the heat of formation of a salt can be simplified by eqn (1), where $\Delta H_{\mathrm{L}}$ is the lattice energy of the ionic salts, which can be predicted by the formula suggested by Jenkins et al., as shown in eqn (2), ${ }^{24}$ where $n_{\mathrm{M}}$ and $n_{\mathrm{X}}$ depend on the nature of the ions $\mathrm{M}_{\mathrm{p}}{ }^{+}$and $\mathrm{X}_{\mathrm{q}}{ }^{-}$, respectively, and are equal to 3 for monatomic ions, 5 for linear polyatomic ions, and 6 for nonlinear polyatomic ions. The equation for the lattice potential energy $U_{\mathrm{POT}}$ $\left(\mathrm{kJ} \mathrm{mol}^{-1}\right)$ has the form of (3), where $\rho\left(\mathrm{g} \mathrm{cm}^{-3}\right)$ is the density, $M$

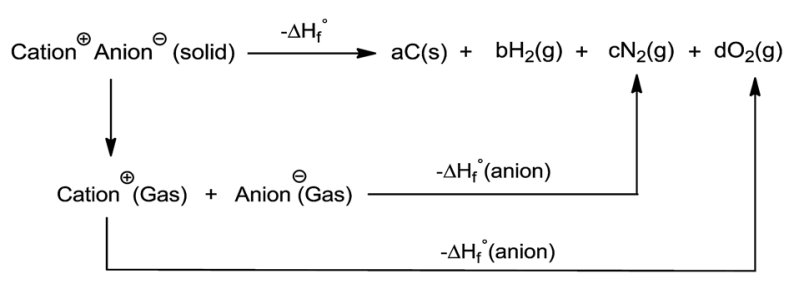

Scheme 1 The Born-Haber energy cycle. $\left(\mathrm{g} \mathrm{mol}^{-1}\right)$ is the chemical formula mass of the ionic compound, and the coefficients $\gamma\left(\mathrm{kJ} \mathrm{mol}^{-1} \mathrm{~cm}\right)$ and $\delta\left(\mathrm{kJ} \mathrm{mol}^{-1}\right)$ were obtained from the literature. ${ }^{24}$

For all the related compounds, the theoretical density was obtained from the molecular weight divided by the average molecular volume, which has been successfully applied to highnitrogen compounds. For an ionic crystal with the formula unit $\mathrm{M}_{\mathrm{p}} \mathrm{X}_{\mathrm{q}}$, where $\mathrm{M}$ denotes the cation and $\mathrm{X}$ denotes the anion, its volume is simply the sum of the volumes of the ions contained in the formula unit. The volume of each ion is defined as inside a contour of 0.001 electrons bohr ${ }^{-3}$ density that was evaluated using a Monte Carlo integration. We performed 100 singlepoint calculations for the optimized structure of each ion to obtain an average volume. The detonation properties of these compounds were calculated using EXPLO 5 (v6.01).

$$
\begin{aligned}
& \Delta H_{\mathrm{f}}^{\circ}(\text { salt, } 298 \mathrm{~K})=\sum \Delta H_{\mathrm{f}}^{\circ}(\text { anion, } 298 \mathrm{~K}) \\
& +\sum \Delta H_{\mathrm{f}}^{\circ}(\text { cation, } 298 \mathrm{~K})-\Delta H_{\mathrm{L}} \\
& \Delta H_{\mathrm{L}}=U_{\text {РОт }}+\left[p\left(n_{\mathrm{M}} / 2-2\right)+q\left(n_{\mathrm{X}} / 2-2\right)\right] R T \\
& U_{\text {РОТ }}\left(\mathrm{kJ} \mathrm{mol}^{-1}\right)=\gamma\left(\rho_{\mathrm{m}} / M_{\mathrm{m}}\right)^{1 / 3}+\delta
\end{aligned}
$$

\section{Results and discussion}

\section{Structures}

Our previous study showed that the M06-2X method was reliable for the optimization of polynitrogen compounds, ${ }^{23}$ based on which we obtained the optimized structures of all the compounds, as depicted in Fig. 2. The structure of the separated $\left[\mathrm{N}_{3} \mathrm{NFO}\right]^{+}$is planar, and it can exist in the form of two stereoisomers depending on whether the azido group and the fluorine ligand are cis ( $Z$ isomer) or trans ( $E$ isomer) with respect to each other. At our employed calculation level, the bond lengths of the $\mathrm{N}-\mathrm{F}$ bonds in the two isomers significantly differ, with the $Z$ isomer exhibiting a longer bond by $0.042 \AA$ (reported $0.046 \AA$ ). ${ }^{8}$ The energy calculation also shows that the $Z$ isomer is favoured by $0.78 \mathrm{kcal} \mathrm{mol}^{-1}$, which is slightly different from $0.6 \mathrm{kcal}$ $\mathrm{mol}^{-1}$ reported in the literature. ${ }^{13}$ Thus, the stable $Z$ isomer was selected for our further investigations.

There are two aspects worth noting in compound 2 (Fig. 2). One interesting case is that the three fluorine ions in $\mathrm{AlF}_{6}{ }^{-}$are obviously separated from the central $\mathrm{Al}$ ion. The partially dissociated Al-F bond suggests that the three $\mathrm{F}$ ions are not strongly bound to the central $\mathrm{Al}$ ion such that $\mathrm{F}$ ion tends to shift to $\left[\mathrm{NF}_{2} \mathrm{O}\right]^{+}$, promoting the decomposition of $\left[\mathrm{NF}_{2} \mathrm{O}\right]^{+}$. However, the shorter $\mathrm{Al}-\mathrm{F}$ bond (1.7012 $\AA$ ) in $\mathrm{AlF}_{4}{ }^{-}$indicates a stronger interaction between $\mathrm{Al}$ and $\mathrm{F}$ than that of $\mathrm{AlF}_{6}{ }^{-}$ $(1.8071 \AA)$, which is relatively more difficult to be broken in the decomposition reaction. The bond strength of the central atom (Al) with the ligand $\left(\mathrm{F}^{-}\right)$in the counter-ion may be significant for the stability of $\left[\mathrm{NF}_{2} \mathrm{O}\right]^{+}$. A similar case exists in $\mathbf{9}$ where the two $\mathrm{F}$ ions are separated from the central $\mathrm{Al}$ ion. Another noteworthy case is the structural destruction of the anion after 

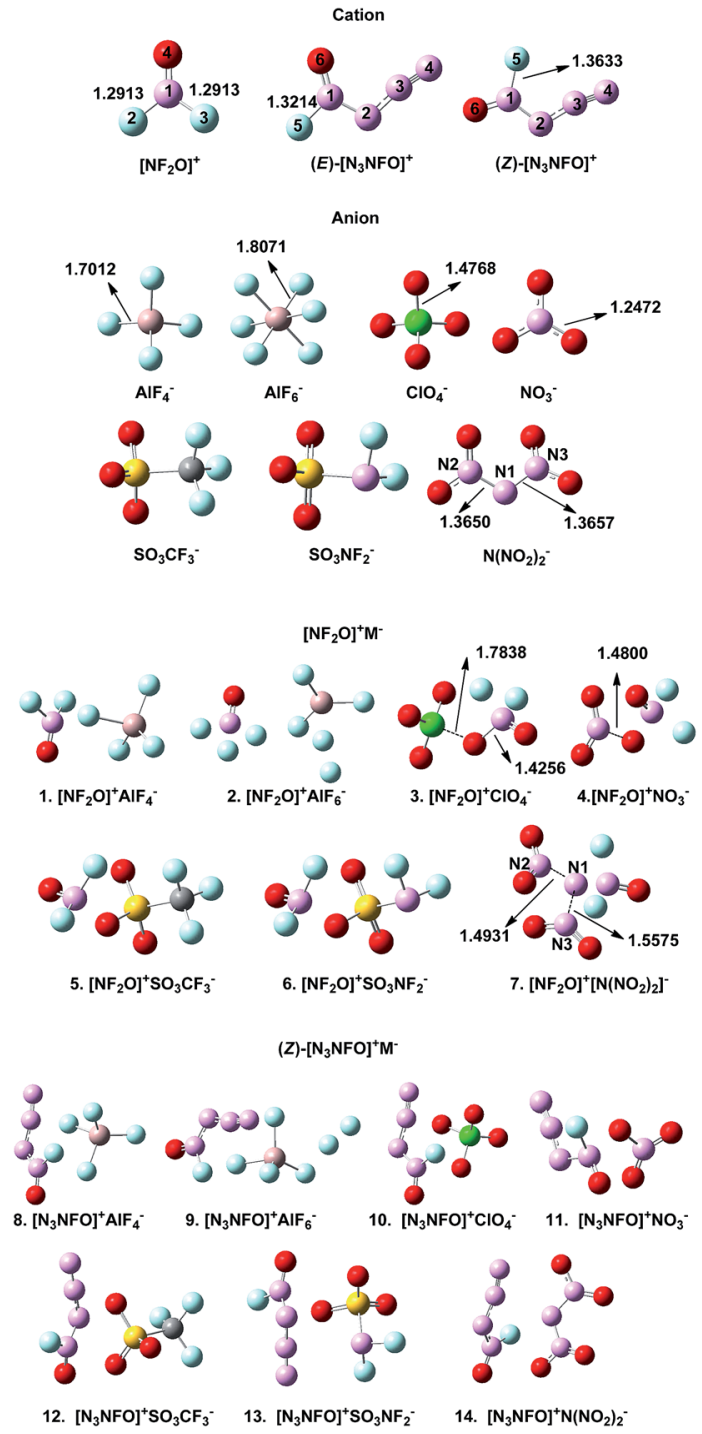

Fig. 2 The optimized structures of the separated $\left[\mathrm{NF}_{2} \mathrm{O}\right]^{+},(Z)-$ $\left[\mathrm{N}_{3} \mathrm{NFO}\right]^{+},(E)-\left[\mathrm{N}_{3} \mathrm{NFO}\right]^{+}$, and $(Z)-\left[\mathrm{NF}_{2} \mathrm{O}\right]^{+} \mathrm{M}^{-}\left(\mathrm{M}^{-}=\mathrm{ClO}_{4}^{-}, \mathrm{NO}_{3}{ }^{-}\right.$, $\mathrm{N}\left(\mathrm{NO}_{2}\right)_{2}{ }^{-}, \mathrm{SO}_{3} \mathrm{CF}_{3}{ }^{-}, \mathrm{SO}_{3} \mathrm{NF}_{2}{ }^{-}, \mathrm{AlF}_{4}{ }^{-}$, and $\mathrm{AlF}_{6}{ }^{-}$).

its combination with $\left[\mathrm{NF}_{2} \mathrm{O}\right]^{+}$, which may be caused by their intermolecular electrostatic interactions. For compounds $\mathbf{3}, \mathbf{4}$, and 7 , when $\mathrm{ClO}_{4}{ }^{-}, \mathrm{NO}_{3}{ }^{-}$, and $\mathrm{N}\left(\mathrm{NO}_{2}\right)_{2}{ }^{-}$are combined with $\left[\mathrm{NF}_{2} \mathrm{O}\right]^{+}$, the stable structures of the anions are interrupted. The $\mathrm{Cl}-\mathrm{O}$ bond noted in 3 is lengthened $(1.7838 \AA)$ when compared with the $\mathrm{Cl}-\mathrm{O}$ bond $(1.4768 \AA)$ in separated $\mathrm{ClO}_{4}{ }^{-}$, resulting in $\mathrm{Cl}-\mathrm{O}$ bond breakage and a newly formed $\mathrm{N}-\mathrm{O}$ bond. A similar bond breakage occurs in 4 in which the $\mathrm{N}-\mathrm{O}$ bond of $\mathrm{NO}_{3}{ }^{-}$is broken with much larger distance of $\mathrm{N}-\mathrm{O}(1.4800 \AA)$ than that of the separated $\mathrm{NO}_{3}{ }^{-}(1.2472 \AA)$. The structure of 7 obviously demonstrates its structural instability, where the distance of $\mathrm{N} 1-\mathrm{N} 2$ and $\mathrm{N} 2-\mathrm{N} 3$ in $\mathrm{N}\left(\mathrm{NO}_{2}\right)_{2}{ }^{-}$is $1.4931 \AA$ and $1.5575 \AA$, respectively, completely decomposing to two separated $\mathrm{NO}_{2}$ molecules in the gas phase.

Based on the inspection of the optimized structures, we preliminarily screened out the possible stable compounds $\mathbf{1}, \mathbf{5}$, $\mathbf{6 , 8}, \mathbf{1 0 - 1 4}$ to carry out further investigations.

\section{Stabilities}

The energies released upon the formation of salts by the isolated ions are reflected in the binding energy $(\Delta E)$ values, which can be expressed by the following equation.

$$
\Delta E=E_{0}(\text { cation })+E_{0}(\text { anion })-E_{0}(\text { salt })
$$

A larger binding energy means greater stability after the formation of the salts. For comparison, the calculated binding energy of $\left[\mathrm{NF}_{2} \mathrm{O}\right]^{+} \mathrm{SbF}_{6}{ }^{-}$and the screened compounds are listed in Table 1. Obviously, each compound has a larger binding energy ranging from 93.4 to $120.8 \mathrm{kcal} \mathrm{mol}^{-1}$ than that of $\left[\mathrm{NF}_{2} \mathrm{O}\right]^{+} \mathrm{SbF}_{6}^{-}\left(\Delta E=89.8 \mathrm{kcal} \mathrm{mol}{ }^{-1}\right)$, indicating they have relatively better stabilities than $\left[\mathrm{NF}_{2} \mathrm{O}\right]^{+} \mathrm{SbF}_{6}{ }^{-}$. For compounds 1 and 8 with the same paired anion $\mathrm{AlF}_{4}{ }^{-}, 8$ gives a larger $\Delta E$, indicating that $(Z)-\left[\mathrm{N}_{3} \mathrm{NFO}\right]^{+}$can better stabilize $\mathrm{AlF}_{4}{ }^{-}$-based salts when compared with $\left[\mathrm{NF}_{2} \mathrm{O}\right]^{+}$. In addition, our calculations show that for the same paired anions, $(Z)-\left[\mathrm{N}_{3} \mathrm{NFO}\right]^{+}$and $(E)$ $\left[\mathrm{N}_{3} \mathrm{NFO}\right]^{+}$-based salts have close $\Delta E$ values with a difference of 2 $\mathrm{kcal} \mathrm{mol}^{-1}$, which is due to the close free energies of separated $(Z)-\left[\mathrm{N}_{3} \mathrm{NFO}\right]^{+}$and $(E)-\left[\mathrm{N}_{3} \mathrm{NFO}\right]^{+} .{ }^{25}$ The data in Table 1 shows compound 5 has the largest binding energy $(\Delta E=120.8 \mathrm{kcal}$ $\mathrm{mol}^{-1}$ ), indicating that it is the most stable salt, whereas $\mathbf{1}$ is the least stable $\left(\Delta E=93.4 \mathrm{kcal} \mathrm{mol}^{-1}\right)$. To sum up, the thermal stability order is $5>6>11>12>8 \approx 14>10>13 \approx 1>$ $\left[\mathrm{NF}_{2} \mathrm{O}\right]^{+} \mathrm{SbF}_{6}{ }^{-}$, based on which it can be inferred that the screened compounds have great possibilities to be synthesized.

The energy gap ( $\left.\Delta E_{\text {LUмо-номо }}\right)$ of the highest occupied molecular orbital (HOMO) and the lowest unoccupied molecular orbital (LUMO) is essential for kinetic stability and chemical reactivity during the chemical processes with electron transfer or leap. ${ }^{26,27}$ The HOMOs and LUMOs of the selected salts are depicted in Fig. 3. For the series of $(E)-\left[\mathrm{N}_{3} \mathrm{NFO}\right]^{+}$salts, the distributions of orbitals and $\Delta E_{\text {LUмо-номо values are }}$ similar to that of the $Z$ isomers, which are not shown. An inspection of Fig. 3 demonstrates that the LUMO orbitals mainly locate on the part of the cations, and the HOMO orbitals mainly locate on the ions. It's well known that a higher energy gap implies lower chemical reactivity and a lower gap implies higher chemical reactivity. Therefore, the $\Delta E_{\text {LUмо-номо values }}$

Table 1 The binding energy $(\Delta E)$ and the energy gaps ( $\Delta E_{\text {LUMO-HOMO }}$ ) of the screened compounds and $\left[\mathrm{NF}_{2} \mathrm{O}\right]^{+} \mathrm{SbF}_{6}$

\begin{tabular}{lcc}
\hline Compd. & $\Delta E\left[\mathrm{kcal} \mathrm{mol}^{-1}\right]$ & $\Delta E_{\text {LUмо-номо }[\mathrm{eV}]}$ \\
\hline$\left[\mathrm{NF}_{2} \mathrm{O}^{+} \mathrm{SbF}_{6}{ }^{-}\right.$ & 89.8 & 7.85 \\
$\mathbf{1}$ & 93.4 & 8.17 \\
$\mathbf{5}$ & 120.8 & 11.02 \\
$\mathbf{6}$ & 114.1 & 9.92 \\
$\mathbf{8}$ & 96.4 & 7.49 \\
$\mathbf{1 0}$ & 95.6 & 5.12 \\
$\mathbf{1 1}$ & 99.0 & 8.72 \\
$\mathbf{1 2}$ & 97.6 & 5.14 \\
$\mathbf{1 3}$ & 93.8 & 5.11 \\
$\mathbf{1 4}$ & 96.3 & 4.77
\end{tabular}




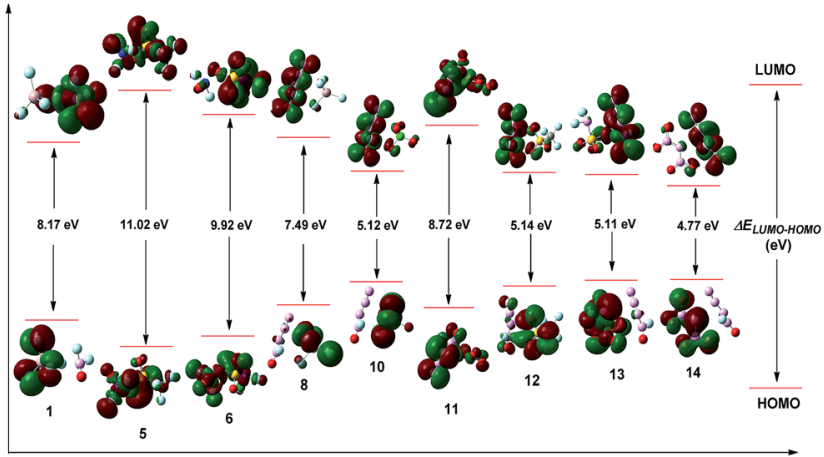

Fig. 3 The depicted HOMOs, LUMOS, and energy gaps ( $\triangle E_{\text {LUMO- }}$ номо) of the selected compounds.

in Table 1 indicate that compounds $\mathbf{1 , 5 , 6}$, and $\mathbf{1 1}$ have lower chemical reactivity than $\left[\mathrm{NF}_{2} \mathrm{O}\right]^{+} \mathrm{SbF}_{6}{ }^{-}$, with $\Delta E_{\text {LUмо-номо }}$ values ranging from $8.17 \mathrm{eV}$ to $11.02 \mathrm{eV}$, and the compound with the lowest chemical reactivity should be $5(11.02 \mathrm{eV})$. In summary, the screened salts have a chemical reactivity order of $5<\mathbf{6}<\mathbf{1 1}<\mathbf{1}<\left[\mathrm{NF}_{2} \mathrm{O}\right]^{+} \mathrm{SbF}_{6}{ }^{-}<\mathbf{8}<\mathbf{1 2} \approx \mathbf{1 3} \approx \mathbf{1 0}<\mathbf{1 4}$.

\section{Energetic properties}

The heat of formation (HOF) is an important parameter to obtain the detonation properties of a compound, and the accurate heats of formation of the cations and anions of the screened compounds were calculated at the G2 level of theory. The lattice energy $\left(\Delta H_{\mathrm{L}}\right)$ was mainly determined by the volume and type of the salt. For all the salts, the ratio of the number of cations to anions was' $1: 1$ and the calculated $\Delta H_{\mathrm{L}}$ values in Table 2 range from 507 to $569 \mathrm{~kJ} \mathrm{~mol}^{-1}$. Due to the low HOF of $\mathrm{AlF}_{4}{ }^{-}$, compounds 1 and 8 with $\mathrm{AlF}_{4}{ }^{-}$as the anion show lower HOFs when compared with other compounds, whose values are -1517 and $-1160 \mathrm{~kJ} \mathrm{~mol}^{-1}$, respectively, among which 14 has the highest positive heat of formation up to $637 \mathrm{~kJ} \mathrm{~mol}^{-1}$. Moreover, all the related salts exhibit certain detonation properties such as detonation velocities $(D)$ and detonation pressures $(P)$, among which 14, composed of $\mathrm{N}\left(\mathrm{NO}_{2}\right)_{2}{ }^{-}$and $\left[\mathrm{N}_{3} \mathrm{NFO}\right]^{+}$, shows a comparable energetic performance with AP and ADN, better than that of other compounds with $\mathrm{NO}_{3}{ }^{-}$, $\mathrm{ClO}_{4}{ }^{-}, \mathrm{AlF}_{4}{ }^{-}, \mathrm{SO}_{3} \mathrm{CF}_{3}{ }^{-}$, and $\mathrm{SO}_{3} \mathrm{NF}_{2}{ }^{-}$as paired anions.

The oxygen balance $(\mathrm{OB})$ indicates the degree to which an explosive can be oxidized. As an important index for identifying the potential of oxidants, compounds with positive OBs indicate that there is enough oxygen in their composition to convert all the carbon and hydrogen atoms to carbon monoxide and water, respectively, whereas negative OBs indicate an insufficient oxygen content for complete oxidation. All the screened salts possess positive OBs ranging from $13 \%$ to $50 \%$. Compounds 1 and 13 have positive OBs of $23 \%$ and $25 \%$, respectively, which are comparable to those of AP and ADN. Particularly, the OBs of $10(50 \%), 11(47 \%)$, and 14 (45\%) are much higher than those of AP and ADN (26\%).

The value of excellent oxidizers can be reflected in the application as propellants. As an important parameter, the specific impulse $\left(I_{\mathrm{s}}\right)$ is used to determine the performance of solid propellants or binders. The $I_{\mathrm{S}}$ values of the relevant compounds were calculated under isobaric conditions at $7 \mathrm{MPa}$ with an initial temperature of $3300 \mathrm{~K}$ using EXPLO5 (v6.01). Compounds 10, 11, and 14 show impulse values of $236 \mathrm{~s}, 264 \mathrm{~s}$, and $260 \mathrm{~s}$, which are much higher than those of $\operatorname{AP}\left(I_{\mathrm{s}}=157 \mathrm{~s}\right)$ and $\operatorname{ADN}\left(I_{\mathrm{s}}=202 \mathrm{~s}\right)$ as neat compounds. The impulse calculations for neat compounds $\mathbf{5}$ and $\mathbf{6}$ were not performed due to the problem of temperature limits during the calculations. The addition of aluminium and PBAN binder as a fuel drastically increases the $I_{\mathrm{s}}$ for all the compounds. We carried out $I_{\mathrm{s}}$ calculations with different combustion parameters: oxidizer/ aluminium/PBAN [\%], and the calculations indicate that the optimized ratio of the mixtures with aluminium and PBAN binder was composed of $76 \%$ oxidizer, $10 \%$ aluminium, and 14\% binder. Surprisingly the calculations show compound 12 achieves the highest $I_{\mathrm{s}}$ value at $464 \mathrm{~s}$, far exceeding that of any other already known solid propellant. This unexpected effect may be caused by the introduction of carbon in $\mathbf{1 2}$ when compared with the other salts. Moreover, compounds 5, 11, 13,

Table 2 Properties of screened $\left[\mathrm{NF}_{2} \mathrm{O}\right]^{+}$and $(Z)-\left[\mathrm{N}_{3} \mathrm{NFO}\right]^{+}$-based oxidizers, AP, and ADN

\begin{tabular}{|c|c|c|c|c|c|c|c|c|c|c|}
\hline Compd. & $\mathrm{OB}^{a}[\%]$ & $\rho^{b}\left[\mathrm{~g} \mathrm{~cm}^{-3}\right]$ & $\Delta H_{\mathrm{L}}^{c}\left[\mathrm{~kJ} \mathrm{~mol}^{-1}\right]$ & $\Delta H_{\mathrm{f}}^{d}\left[\mathrm{~kJ} \mathrm{~mol}^{-1}\right]$ & $V_{\mathrm{D}}^{e}\left[\mathrm{~km} \mathrm{~s}^{-1}\right]$ & $P^{f}[\mathrm{GPa}]$ & $I_{\mathrm{s}}^{g}[\mathrm{~s}]$ & $I_{\mathrm{s}}^{h}[\mathrm{~s}]$ & $I_{\mathrm{s}}^{i}[\mathrm{~s}]$ & $I_{\mathrm{s}}^{j}[\mathrm{~s}]$ \\
\hline 1 & 23 & 2.18 & 569 & -1517 & 2.69 & 2.3 & 138 & 216 & 227 & 239 \\
\hline 5 & 18 & 1.82 & 507 & -947 & 4.51 & 12.0 & - & 324 & 263 & 244 \\
\hline 8 & 17 & 2.03 & 539 & -1160 & 5.14 & 11.1 & 187 & 220 & 217 & 205 \\
\hline 10 & 50 & 1.97 & 538 & 389 & 6.61 & 19.0 & 236 & 297 & 289 & 271 \\
\hline 11 & 47 & 1.80 & 557 & 413 & 7.03 & 20.0 & 264 & 309 & 296 & 284 \\
\hline 14 & 45 & 1.85 & 524 & 637 & 7.56 & 23.9 & 260 & 309 & 294 & 286 \\
\hline $\mathrm{ADN}^{28}$ & 26 & 1.81 & - & -150 & 7.86 & 23.6 & 202 & 264 & 269 & 202 \\
\hline $\mathrm{AP}^{29}$ & 26 & 1.95 & - & -296 & 6.37 & 15.8 & 157 & 256 & 261 & 244 \\
\hline
\end{tabular}

${ }^{a}$ Oxygen balance. ${ }^{b}$ Density. ${ }^{c}$ Lattice energy. ${ }^{d}$ Calculated enthalpy of formation (kJ mol $\left.{ }^{-1}\right) .{ }^{e}$ Detonation velocity. ${ }^{f}$ Detonation pressure. ${ }^{g}$ Specific impulse(s) of neat compounds. ${ }^{h}$ Specific impulse(s) of mixtures with aluminium and/or PBAN binder as $76: 10: 14$. Binder composition $6 \%$ polybutadiene acrylic acid, $6 \%$ polybutadiene acrylonitrile and $2 \%$ bisphenol A ether. ${ }^{i}$ Original NASA composition (70:16:14) for the space shuttle solid rocket boosters. ${ }^{j}$ Specific impulse(s) of mixtures with aluminium and/or PBAN binder as $80: 20: 0$. 
and $\mathbf{1 4}$ are quite promising oxidizers, with superior $I_{\mathrm{S}}$ values $(>300 \mathrm{~s})$ relative to those of $\mathrm{AP}\left(I_{\mathrm{s}}=256 \mathrm{~s}\right)$ and $\mathrm{ADN}\left(I_{\mathrm{s}}=264 \mathrm{~s}\right)$ with similar formulations. Our calculations show that the $I_{\mathrm{S}}$ values of all the screened oxidizers were superior to those of AP and ADN, except for $\mathbf{1}$ and $\mathbf{8}$. Considering the relative thermal stability and chemical reactivity discussed above, the calculation results suggest that compounds $\mathbf{5}$ and $\mathbf{1 1}$ may be used as a new generation of superenergetic oxidizers with potential applications as solid rocket propellants.

\section{Conclusions}

A series of $\left[\mathrm{NF}_{2} \mathrm{O}\right]^{+}$and $\left[\mathrm{N}_{3} \mathrm{NFO}\right]^{+}$-based energetic oxidizers were designed employing density functional theory. The calculated binding energies indicate that compounds $\mathbf{1 , ~ 5 , ~ 6 , ~ 8 , ~ 1 0 - 1 4 ~}(\Delta E>$ $93 \mathrm{kcal} \mathrm{mol}^{-1}$ ) have better thermal stabilities than previously reported $\mathrm{NF}_{2} \mathrm{OSbF}_{6}\left(\Delta E=89.8 \mathrm{kcal} \mathrm{mol}^{-1}\right)$. The energy gap $\left(\Delta E_{\mathrm{LUMO}-\text {-омо }}\right)$ analysis predicted that $1,5,6$, and 11 exhibit a lower chemical reactivity than $\mathrm{NF}_{2} \mathrm{OSbF}_{6}$, in which $\mathbf{5}$ has the lowest chemical reactivity. Amazingly with good thermal stabilities, compounds 5, 11-14 show superior $I_{\mathrm{s}}$ values (>300 s) to those of ammonium perchlorate (AP) and ammonium dinitramide (ADN) with an optimized ratio of oxidizer/aluminium/ PBAN (\%) of $76: 10: 14$. While considering the kinetic stability, compounds $\mathbf{5}$ and $\mathbf{1 1}$ may be used as potential solid propellants. Moreover, our exploration using experiments is currently underway. We hope our work may supply new insight into the expansion of novel energetic oxidizers and candidates for future solid propellants.

\section{Conflict of interest}

The authors declare no competing financial interest.

\section{Acknowledgements}

The authors acknowledge the financial support received from the National Natural Science Foundation of China (21576026 and U1530262).

\section{Notes and references}

1 X. X. Zhao, S. H. Li, Y. Wang, Y. C. Li, F. Q. Zhao and S. P. Pang, J. Mater. Chem. A, 2016, 4, 5495-5504.

2 Q. J. Axthammer, B. Krumm and T. M. Klapötke, J. Org. Chem., 2015, 80, 6329-6335.

3 R. P. Singh, R. D. Verma, D. T. Meshri and J. n. M. Shreeve, Angew. Chem., Int. Ed., 2006, 45, 3584-3601.

4 D. M. Badgujar, M. B. Talawar, S. N. Asthana and P. P. Mahulikar, J. Hazard. Mater., 2008, 151, 289-305.

5 C. Darwich, T. M. Klapötke and C. M. Sabaté, Chem.-Eur. J., 2008, 14, 5756-5771.
6 R. Wang, H. Xu, Y. Guo, R. Sa and J. n. M. Shreeve, J. Am. Chem. Soc., 2010, 132, 11904-11905.

7 T. Fendt, N. Fischer, T. M. Klapötke and J. Stierstorfer, Inorg. Chem., 2011, 50, 1447-1458.

8 C. B. Jones, R. Haiges, T. Schroer and K. O. Christe, Angew. Chem., Int. Ed., 2006, 45, 4981-4984.

9 W. Liu, Q.-H. Lin, Y.-Z. Yang, X.-J. Zhang, Y.-C. Li, Z.-H. Lin and S.-P. Pang, Chem.-Asian J., 2014, 9, 479-486.

10 G. W. Drake, S. Bolden, J. Dailey, M. J. McQuaid and D. Parrish, Propellants, Explos., Pyrotech., 2012, 37, 40-51.

11 C. A. Wamser, W. B. Fox, B. Sukornick, J. R. Holmes, B. B. Stewart, R. Juurik, N. Vanderkooi and D. Gould, Inorg. Chem., 1969, 8, 1249-1253.

12 K. O. Christe and D. A. Dixon, J. Am. Chem. Soc., 1992, 114, 2978-2985.

13 V. Plato, W. D. Hartford and K. Hedberg, J. Chem. Phys., 1970, 53, 3488-3494.

14 W. B. Fox, J. S. MacKenzie and R. Vitek, Inorg. Nucl. Chem. Lett., 1970, 6, 177-179.

15 W. H. Kirchhoff and D. R. Lide Jr, J. Chem. Phys., 1969, 51, 467-468.

16 R. R. Smardzewski, J. Chem. Phys., 1974, 60, 2193.

17 S. Abramowitz and I. W. Levin, J. Chem. Phys., 1969, 51, 463464.

18 K. O. Christe, W. W. Wilson, J. A. Sheehy and J. A. Boatz, Angew. Chem., Int. Ed., 1999, 38, 2004-2009.

19 K. O. Christe and W. Maya, Inorg. Chem., 1969, 8, 1253-1257. 20 W. W. Wilson, R. Haiges, J. A. Boatz and K. O. Christe, Angew. Chem., Int. Ed., 2007, 46, 3023-3027.

21 Y. Yu, Y.-c. Li, J.-f. Chen, C.-h. Sun, J.-s. Li, G.-j. Fan, S.-p. Pang and R.-b. Zhang, RSC Adv., 2015, 5, 104841104845.

22 M. T. Nguyen and T.-K. Ha, Chem. Phys. Lett., 2000, 317, 135141.

23 C. Qi, R.-B. Zhang and S.-P. Pang, RSC Adv., 2013, 3, 1774117748.

24 H. D. B. Jenkins, D. Tudela and L. Glasser, Inorg. Chem., 2002, 41, 2364-2367.

25 T. Yu, Y.-Z. Liu, R. Haiges, K. O. Christe, W.-P. Lai and B. Wu, RSC Adv., 2014, 4, 28377-28389.

26 Z. Zhou and R. G. Parr, J. Am. Chem. Soc., 1989, 111, 73717379.

27 Y.-F. Li, X.-W. Fan, Z.-Y. Wang and X.-H. Ju, J. Mol. Struct.: THEOCHEM, 2009, 896, 96-102.

28 M. r. Y. Nagamachi, J. I. S. Oliveira, A. M. Kawamoto and R. d. C. s. L. Dutra, J. Aerosp. Technol. Manage., 2009, 1, 153-160.

29 E. Gökcinar and T. M. Klapötke, Turk. J. Chem., 2010, 34, 953-967. 